\title{
基 \\ Assessment of the efficacy of commercial anthelmintics in horses naturally infected with gastrointestinal nematodes
}

\author{
[Avaliação da eficácia de anti-helmínticos comerciais em equinos naturalmente infectados com \\ nematódeos gastrintestinais]
}

\section{"Short Communication/Comunicação Breve"}

\author{
Natália Soares Martins ${ }^{*}$, Diego Moscarelli Pinto ${ }^{2}$, Laís Leal da Cunha ${ }^{3}$, Júlia Somavilla Lignon ${ }^{4}$, \\ Thais Cozza dos Santos², Tainá Ança Evaristo², Felipe Geraldo Pappen², \\ Leandro Quintana Nizoli²
}

\begin{abstract}
${ }^{1}$ Departamento de Microbiologia e Parasitologia, Universidade Federal de Pelotas, Pelotas-RS, Brasil.
${ }^{2}$ Departamento de Veterinária Preventiva, Universidade Federal de Pelotas, Pelotas-RS, Brasil.

${ }^{3}$ Departamento de Plantas Forrageiras e Agrometeorologia, Universidade Federal do Rio Grande do Sul. Porto Alegre-

RS, Brasil.

${ }^{4}$ Departamento de Microbiologia e Parasitologia, Universidade Federal de Santa Maria. Santa Maria-RS, Brasil.

*Corresponding author/Autor para correspondência: E-mail: nataliasmartins@outlook.com
\end{abstract}

\begin{abstract}
The objective of this study was to assess the efficacy of commercial anthelmintics in horses naturally infected with gastrointestinal nematodes from the southern Rio Grande do Sul state, Brazil. The anthelmintic efficacy was assessed by fecal egg count reduction test (FECRT) and coproculture. Fecal samples were collected from 110 animals in seven farms located in the southern region of the state of Rio Grande do Sul, in the south of Brazil. Criteria used to suspect anthelmintic resistance included percentages of efficacy lower than $95 \%$ and a lower limit of the confidence interval below $90 \%$. Anthelmintic resistance was detected in five of the seven farms studied. Coproculture results show that, even after horses were treated with anthelmintics, infection by nematodes of the subfamily Cyathostominae was still present in animals from five farms.
\end{abstract}

Keywords: equine; anthelmintic resistance; cyathostomins.

\section{Resumo}

O objetivo deste estudo foi avaliar a eficácia de anti-helmínticos comerciais em equinos naturalmente infectados por nematódeos gastrintestinais. Para tanto, foi realizado o Teste de Redução de Contagem de Ovos Fecais (TRCOF) e coprocultura. As amostras fecais foram coletadas de 110 equinos provenientes de sete criatórios da região sul do Rio Grande do Sul. Consideraram-se, como critérios para a suspeita de resistência, percentuais de eficácia inferiores a $95 \%$ e limite inferior do intervalo de confiança abaixo de $90 \%$. A resistência anti-helmíntica foi detectada em cinco das sete propriedades analisadas, nas quais observou-se a presença de nematódeos da subfamília Cyathostominae nas coproculturas.

Palavras-chave: equino; resistência anti-helmíntica; ciatostomíneos.

\section{Introdução}

Horse breeding is an important economic activity. In order to achieve the best results during this process, the implementation of efficient health control measures is essential. Surveys on the occurrence of internal parasites in one particular geographic region helps the veterinarian to choose the best drug to treat helminth infections in the equine population living in that area (Matthews, 2014).

Horses host a wide variety of endoparasites which belong to the Phylum Nematoda (ascarids, oxyurids, strongylids, and trichostrongylids), representing the largest group of helminths that 
infect these animals. Nematode infections result in significant economic losses to equine breeding. Helminths of the gastrointestinal system of horses may cause mild abdominal discomfort followed or not by weakness, dull hair coat, growth retardation, anemia, diarrhea or constipation, ultimately fulminant episodes of colic and death (Taylor et al., 2017).

Nematodes of the family Strongylidae are among the helminths that parasitize horses. These are further divided into the subfamilies Strongylinae (popular name: "large strongyles") and Cyathostominae, ("cyathostomins" or "small strongyles"). The relevance of cyathostomins is related to diversity of genera and species, life cycle with hypobiotic stages, and development of anthelmintic resistance (Kaplan and Nielsen, 2010).

For decades, large strongyles, especially Strongylus vulgaris, were considered a major threat to equine health, and over the years they have been the target of parasite control programs (Drudge and Lyons, 1966). These authors suggest that anthelmintics should be administered to horses every eight weeks in order to interrupt the life cycle of the parasite. This strategy was widely used and successfully reduced $S$. vulgaris populations (Herd, 1990). However, this method allowed an increase in the prevalence of cyathostomins, especially due to their adaptability to new molecules and types of treatment (Kaplan and Nielsen, 2010). The current consensus is that cyathostomins are the main group of endoparasites in horses (Nielsen, 2012).

The control of helminth infections results in a better performance of the animals. In most of the breeding stocks, anthelmintic compounds are intensively used due to its convenience, efficiency, and safety regarding the health of these animals. However, the indiscriminate use of these compounds favors the development of anthelminthic resistance which compromise the efficacy of the treatment (Kaplan and Nielsen, 2010). Anthelmintic resistance in horses is common, and there are several published studies which report reduced efficacy of antiparasitic compounds worldwide, including in Brazil (Kaplan et al., 2004; Traversa et al., 2007; Molento et al., 2008; Cerutti et al., 2012). Effective anthelmintic control relies on regular coproparasitological examinations, follow-up care by veterinarians, and implementation of adequate control strategies in each farm.

The present study aimed at assessing the efficacy of commercial anthelmintics in horses from the southern region of the State of Rio Grande do Sul, in southern Brazil, which were naturally infected with gastrointestinal parasites.

A total of 150 fecal samples of Criollo horses from seven farms of Rio Grande do Sul, southern region, were collected in this study for parasitological examination. Horses were between two and 10 years of age. These were naturally infected animals raised in a farm in an extensive system (rangeland). All farms had veterinary medical assistance, and these practitioners decided which anthelmintic to use in these animals and how often these drugs were administered to these animals. In none of the premises there was a history of assessment of anthelmintic resistance.

Stool samples were collected, directly from the rectum, and were analyzed using the modified McMaster technique (Ueno and Gonçalves, 1998). Animals that had EPG (eggs per gram of feces) above 500 were included in the study $(n=110)$. Anthelmintics in paste formulation were administered in a single oral dose. The active principle used was chosen by the veterinarian overseeing the farm; treatments and doses are described in Table 1. After 14 days of anthelmintic treatment, fecal samples from the same animals were collected and analyzed as previously described to obtain the EPG post-treatment. The fecal egg count reduction test (FECRT) was performed according to the protocol published by Coles et al. (1992). Post-treatment coproculture (Roberts and O'Sullivan, 1950) was performed to determine the type of strongylid that was infecting these horses.

The statistical method used was the hierarchical modelling of fecal egg count developed by Wang et al. (2017). The lower and upper limits of the confidence interval were also calculated at $95 \%$. We used percentages of effectiveness lower than $95 \%$ and a lower limit of the confidence interval below $90 \%$ as criteria to suspect anthelmintic resistance (Coles et al., 1992). Chi-square test with significance level of $p<0.05$ to verify the association between parasites occurrence and the horse's age, sex and breeding system was used with EpiTools epidemiological calculators (Sergeant, 2018). 
Table 1. Arithmetic mean of nematode eggs per gram of feces (EPG) and effectiveness indexes (EFI) of commercial anthelmintics in horses from southern Rio Grande do Sul state, Brazil.

\begin{tabular}{|c|c|c|c|c|c|c|c|}
\hline Farm & $\mathrm{N}^{1}$ & Treatment $^{2}$ & Dose & $\begin{array}{c}\text { Mean EPG pre- } \\
\text { treatment }\end{array}$ & $\begin{array}{c}\text { Mean EPG post- } \\
\text { treatment }\end{array}$ & $\operatorname{EFI}(\%)$ & $\mathrm{CI}^{3}(\%)$ \\
\hline I & 10 & MEB & $10 \mathrm{mg} / \mathrm{kg}$ & 881.91 & 866.89 & 1.2 & $0-6.1$ \\
\hline II & 20 & CLO+ALB & $20 \mathrm{mg} / \mathrm{kg}+5 \mathrm{mg} / \mathrm{kg}$ & 1084.45 & 464.05 & 57.1 & $49.2-64.2$ \\
\hline III & 16 & MOX & $0.4 \mathrm{mg} / \mathrm{kg}$ & 550.76 & 103.9 & 81.1 & $72.6-87.4$ \\
\hline IV & 16 & $\mathrm{IVM}+\mathrm{PRA}$ & $\begin{array}{c}0.2 \\
\mathrm{mg} / \mathrm{kg}+2.5 \mathrm{mg} / \mathrm{kg}\end{array}$ & 1219.81 & 229.82 & 81.2 & $76-85.7$ \\
\hline V & 18 & IVM+PRA & $\begin{array}{c}0.2 \\
\mathrm{mg} / \mathrm{kg}+2.5 \mathrm{mg} / \mathrm{kg}\end{array}$ & 1210.11 & 108.39 & 91.1 & $87.6-93.7$ \\
\hline VI & 10 & IVM+PRA & $\begin{array}{c}0.2 \\
\mathrm{mg} / \mathrm{kg}+2.5 \mathrm{mg} / \mathrm{kg}\end{array}$ & 1530.13 & 3.71 & 99.8 & $98.7-100$ \\
\hline VII & 20 & IVM+PRA & $\begin{array}{c}0.2 \\
\mathrm{mg} / \mathrm{kg}+2.5 \mathrm{mg} / \mathrm{kg}\end{array}$ & 1583.88 & 1.81 & 99.9 & $99.4-100$ \\
\hline
\end{tabular}

${ }^{1} \mathrm{~N}=$ number of samples collected in each farm

${ }^{2}$ Anthelmintics used in treatment of parasitic infections of horses = MEB: mebendazole; CLO+ALB: closantel-albendazole; MOX: moxidectin; IVM+PRA: ivermectin- praziquantel

${ }^{3} \mathrm{CI}=$ confidence interval

Eggs containing a morula typical of nematode eggs from the family Strongylidae were found in fecal samples from all horses via coproparasitogical examination. Pre and post treatment mean and reduction results of EPG for gastrointestinal nematodes in the horses examined are presented in Table 1. Five farms had effectiveness indexes (EFI) below 95\%. This finding indicates that there was anthelmintic resistance in these farms. In these farms, larvae with morphological characteristics of the cyathostomins were seen in post-treatment coproculture. In addition, there was no statistical difference regarding age, sex and breed between the horses in this study ( $>>0.05)$.

Benzimidazole resistance is the most common and widespread type of anthelmintic resistance in cyathostomins, and has been reported in 14 countries (Peregrine et al., 2014). This group includes mebendazole and albendazole. In the present study, the most surprising result occurred in Farm I, in which mebendazole was highly ineffective, with an efficacy index (EFI) close to 1\%. In Farm II, the use of a closantel-albendazole combination was also ineffective (EFI: $57.1 \%$ ). Although the use of this combination is not very common, there is one published report on the resistance to these compounds in Brazil (Borges et al., 2010).

Among the drugs used to control parasites in horses, moxidectin is the only one with some action against encysted cyathostomins, and is recommended for the control of this group of nematodes. A high effectiveness index is reported for this drug (Nogueira et al., 2002; Traversa et al.,
2007). However, reduced efficacy of moxidectin (MOX) against cyathostomins has also been described in Brazil (Molento et al., 2008). These results are similar to the findings of our study, where a moxidectin EFI of $81.1 \%$ was observed (Farm III).

There was variation in the results when an ivermectin-praziquantel combination was used. In Farms IV and V, satisfactory indexes were not reached using these drug combinations, with EFI $81.2 \%$ and $91.1 \%$, respectively. Anthelmintic resistance was present in these populations. However, effectiveness indexes of $99.8 \%$ and 99.9\% were found in Farms VI in VII, which suggests that the ivermectin-praziquantel combination was effective against gastrointestinal parasites in those farms. These results corroborate the data published by Dobrowolski et al. (2016), who obtained satisfactory results with the use of ivermectin against cyathostomins in Brazil.

Discrepancy between results may be explained by different management practices used in each farm. In Farms VI and VII, the ivermectinpraziquantel combination was used for more than 1 year, and was administered every six months to only a few groups of horses. In the other farms, all the horses were treated with antiparasitic drugs every two or three months, and at each administration a different active principle was used. Although rapid rotation of different active principles is suggested as a strategy to prevent development of anthelmintic resistance, there is no scientific evidence to support such strategy (Kaplan and Nielsen, 2010). This practice may also hide the occurrence of resistance against 
antiparasitic drugs (Reinemeyer and Henton, 1987). In addition, these findings suggest that the higher the frequency of anthelmintic treatments is, the higher will be the probability of the emergence of drug-resistant cyathostomins, as demonstrated by other authors in previous studies (Kaplan et al., 2004; Traversa et al., 2007), since this method leads to a selection pressure for anthelmintic resistance especially in cyathostomins (Matthews, 2014).

The results of our study highlight the increasing importance of cyathostomins in equine health. Nematodes from this subfamily are the most prevalent and present the highest parasitic intensity in horses in Brazil, representing $80-100 \%$ of the total parasitic load in equine populations of the country (Barbosa et al., 2001; Pereira and Vianna, 2006).

An efficient control of helminth infections is very important especially in adult horses because these animals are a source of pasture contamination which influence the infection of foals (fecal-oral transmission). Development of antiparasitic resistance seems to be increasing over the years, and no new classes of compounds appear to be in development by drug companies or at research laboratories for the use in horses in near future (Matthews, 2014).

In the present study, monitoring of the anthelmintic effectiveness was not performed on the farms visited, and there was no information about resistance to any of the active principles used. Therefore, the use of parasitogical examination for the diagnosis of helminth infections in horses is essential in the monitoring of the drug efficacy in each farm. Preventive control measures (pasture management, selective treatment, maintaining a nematode population in refugia, for example) should be combined with anthelmintic administration so that the anthelmintic resistance does not occur.

There are populations of parasites of the subfamily Cyathostominae that are resistant to mebendazole, moxidectin, closantel-albendazole combination and ivermectin-praziquantel combination in horses from the southern region of the State of Rio Grande do Sul, in the south of Brazil. To the authors' knowledge, the present study is the first one to report resistance of cyathostomins to moxidectin and to the ivermectinpraziquantel combination in horse herds from Rio Grande do Sul.

\section{Conflict of interest}

The authors declare that there is no conflict of interest regarding the publication of this article.

\section{Ethics Committee}

This research proposal was approved by the Animal Experimentation Ethics Committee from Universidade Federal de Pelotas (UFPel) in Brazil (permit 7888).

\section{Acknowledgments}

This study was financed in part by the Coordenação de Aperfeiçoamento de Pessoal de Nível Superior - Brasil (CAPES) - Finance Code 001. The authors would also like to express their gratitude and appreciation to the farmers and veterinarians who participated in this research.

\section{References}

Barbosa, O.F.; Rocha, U.F.; Silva, G.S.; Soares, V.E.; Veronez, V.A.; Oliveira, G.P.; Landim, V.J.C.; Costa, A.J. A survey on Cyathostominae nematodes (Strongylidea, Strongylidae) in pasture bred horses from São Paulo State, Brazil. Semina: Ciências Agrárias, 22: 21-26, 2001.

Borges, F.A.; Nakamura, A.Y.; Almeida, G.D.; Cadamuro, V.H.A. Eficácia de formulações anti-helmínticas comerciais em equinos no município de Douradina, Paraná. Ciência Animal Brasileira, 11(3): 618-622, 2010.

Cerutti, J.; Cooper, L.; Caffe, G.; Cervilla, N.; Muchiut, S.; Anziani, O. Resistencia de los pequeños estrongílidos (grupo ciatostoma) a los bencimidazoles en equinos del área central de Argentina. Investigación Veterinaria, 14(1): 41-46, 2012.

Coles, G.C.; Bauer, C.; Borgsteede, F.H.; Geerts, S.; Klei, T.R.; Taylor, M.A.; Waller, P.J. World Association for the Advancement of Veterinary Parasitology (W.A.A.V.P.) methods for the detection of anthelmintic resistance in nematodes of veterinary importance. Veterinary Parasitology, 44: 35-44, 1992.

Dobrowolski, E.C.; Slompo, D.; Carrasco, A.O.T.; Seki, M.C. Eficácia do praziquantel e da ivermectina em equinos infectados naturalmente com ciatostomíneos. Revista Acadêmica Ciência Animal, 14: 75-81, 2016.

Drudge, J.H.; Lyons, E.T. Control of internal parasites of the horse. Journal of the American Veterinary Medical Association, 148: 378383, 1966. 
Herd, R.P. The changing world of worms: the rise of the cyathostomes and the decline of Strongylus vulgaris. Compendium on Continuing Education for the Practising Veterinarian, 12(5): 732-736, 1990.

Kaplan, R.M.; Klei, T.R.; Lyons, E.T.; Lester, G.D.; French, D.D.; Tolliver, S.C.; Vidyashankar, A.N.; Zhao, Y. Prevalence of anthelmintic resistant cyathostomes on horse farms. Journal of the American Veterinary Medical Association, 225: 903-910, 2004.

Kaplan, R.M.; Nielsen, M.K. An evidence-based approach to equine parasite control: It ain't the 60's anymore. Equine Veterinary Education, 22(6): 306-316, 2010.

Matthews, J.B. Anthelmintic resistance in equine nematodes. International Journal for Parasitology: Drugs and Drug Resistance, 4: 310-315, 2014.

Molento, M.B.; Antunes, J.; Bentes, R.N.; Coles, G.C. Anthelmintic resistant nematodes in Brazilian horses. Veterinary Record, 162(12): 384-385, 2008.

Nielsen, M.K. Sustainable equine parasite control: Perspectives and research needs. Veterinary Parasitology, 185: 32-44, 2012.

Nogueira, C.E.W.; Lima, A.P.; Ruas, J.; Jardim, A.L. Eficácia de vermífugos à base de avermectinas e milbemicinas utilizados há cinco anos em uma criação de eqüinos. Ciência Rural, 32(4): 703-705, 2002.

Peregrine, A.S.; Molento, M.B.; Kaplan, R.M.; Nielsen, M.K. Anthelmintic resistance in important parasites of horses: Does it really matter? Veterinary Parasitology, 201: 1-8, 2014.

Pereira, J.R.; Vianna, S.S.S. Gastrointestinal parasitic worms in equines in the Paraiba Valley, State of São Paulo, Brazil. Veterinary Parasitology, 140: 289-295, 2006.

Reinemeyer, R.; Henton, J.E. Observations on equine strongyle control in southern temperate USA. Equine Veterinary Journal, 19(6): 5058, 1987.

Roberts, F.H.S.; O’Sullivan, J.P. Methods for egg counts and larval cultures for strongyles infesting the gastrointestinal tract of cattle. Australian Journal of Agricultural Research, 1(1): 99-102, 1950.

Sergeant E.S.G. Epitools Epidemiological Calculators. Ausvet. 2018. Available at: <http://epitools.ausvet.com.au> Accessed at: 15 jul. 2020.

Taylor, M.A.; Coop, R.L., Wall, R.L. Parasitologia Veterinária. $4^{\text {a }}$ ed. Rio de Janeiro: Guanabara Koogan, 2017. 1052p.

Traversa, D.; Klei, T.R.; Iorio, R.; Paoletti, B.; Lia, R.P.; Otranto, D.; Otranto, D.; Sparagano, O.A.; Giangaspero, A. Occurrence of anthelmintic resistant equine cyathostome populations in central and southern Italy. Preventive Veterinary Medicine, 82: 314-320, 2007.

Ueno H.; Gonçalves P.C. Manual para diagnóstico das helmintoses de ruminantes. $4^{\mathrm{a}}$ ed. Tokyo, JICA, 1998. p.16-18.

Wang, C.; Torgerson, P.R.; Höglund, J.; Furrer, R. Zero-inflated hierarchical models for faecal egg counts to assess anthelmintic efficacy. Veterinary Parasitology, 235: 20-28, 2017. 